\title{
Endocrine disruptor screening: regulatory perspectives and needs
}

\author{
Markus Hecker ${ }^{1 *}$ and Henner Hollert ${ }^{2 *}$
}

\begin{abstract}
National and international governments are in the process of establishing testing programs and strategies to assess the safety of currently used chemicals with regard to their potential to interact with the endocrine system of man and wildlife, resulting in potential impacts on reproduction, growth, and/or development. Specifically, the USA, Japan, EU, and OECD have established testing approaches and regulatory frameworks with aim to assess the risks associated with chemicals that have endocrine disrupting properties (EDCs). While there has been a large amount of efforts over the past two decades in context with the assessment of chemical safety, no comparable attempts to harmonize and mutually accept testing strategies and decision-making criteria for environmental monitoring and assessment exist to date for EDCs. In fact, many of the current environmental programs such as the European Water Framework Directive (WFD) or the US Clean Water Act do not explicitly test for EDCs, and considering the unique requirements and endpoints required to assess the endocrine potential of a sample, these programs are unlikely to appropriately address exposure to these chemicals. This is of great concern since EDCs are ubiquitous in the environment, especially in aquatic ecosystems. One of most important sources for EDCs in the environment is the effluent from sewage treatment plants. Many EDCs such as the natural and synthetic estrogens $17 \beta$-estradiol and $17 \alpha$-ethinylestradiol, respectively, are not completely removed with conventional wastewater treatment systems. In recognition of these concerns, in Europe, there is increasing pressure to further develop advanced wastewater treatment methods, such as ozonation and activated carbon treatment for a broad application in municipal wastewater treatment. Another issue is the continuing lack of understanding of the environmental relevance of the phenomenon of ED. A great number of studies have been conducted to describe potential ED in wild and laboratory animals. Most of these studies relied on biomarkers of estrogenicity such as vitellogenin induction in males and mild histological alterations (e.g. occurrence of testicular oocytes), and to date - with few exceptions - no convincing evidence of population relevant impacts of exposure to EDC in the wild exist. In conclusion, while there has been a great deal of research and efforts in context with the hazard assessment and regulation of EDCs, there is still a large number of remaining uncertainties and issues. These range from animal rights concerns due to significant increases in the use of animals to fulfill testing requirements, associated needs for alternative testing concepts such as in vitro, in silico, and modeling approaches, lack of understanding of the relevance of the exposure of man and wildlife to EDCs, and the need for inclusion of EDCs in current environmental programs such as the WFD. In this article we attempted to summarize the current state-of-the-art of regulatory and scientific approaches in context with EDCs, and to identify issues and future needs to address current shortcomings in the field.
\end{abstract}

\footnotetext{
* Correspondence: markus.hecker@usask.ca; henner.hollert@bio5.rwth-aachen.

de

${ }^{1}$ Toxicology Centre, University of Saskatchewan, 44 Campus Drive, Saskatoon, SK S7N 5B3, Canada

${ }^{2}$ Department of Ecosystem Analysis, Institute for Environmental Research,

RWTH Aachen University, Worringerweg 1, 52074 Aachen, Germany

Full list of author information is available at the end of the article
}

SpringerOpen $^{\odot}$ (c) 2011 Hecker and Hollert; licensee Springer. This is an Open Access article distributed under the terms of the Creative Commons Attribution License (http://creativecommons.org/licenses/by/2.0), which permits unrestricted use, distribution, and reproduction in any medium, provided the original work is properly cited. 


\section{Background}

Since the middle of the 1990 s, there has been increasing awareness and concern regarding the exposure to chemicals that have the potential to interfere with the endocrine system, and thus, may cause health effects in people and wildlife. In fact, a great number of chemicals have been identified that were found to interact with the endocrine system of different animals in laboratory studies, and there are increasing reports of endocrine disruption in wild animals [1,2]. The potential role of endocrine disrupting chemicals in the environment has been discussed extensively for several years in both science and the broader public. On the one hand, there is evidence from various laboratory experiments that estrogenic or estrogen-like compounds have the potential of affecting development of the reproductive and nervous systems, as well as behavior and immune response in higher organisms [3,4]. On the other hand, it is still unclear if environmentally relevant concentrations of xenoestrogens can result in deleterious effects in wildlife populations, and to date - with few exceptions - there has been no direct evidence of such population relevant impacts in the wild [5,6]. In fact, few studies have attempted to explore the ecological relevance of the exposure to endocrine active chemicals under field conditions. One example is a recent wholelake study that was conducted over 10 years at the Experimental Lakes Area in Canada that revealed clear evidence that the potent synthetic estrogen $17 \beta$-ethynylestradiol (EE2) affects fish populations and their supporting food web [7]. The population of the shortestlived fish species, the fathead minnow, collapsed after two summers of EE2 additions. There is consequently an urgent need in understanding the relevance of labbased experiments with endocrine disruptive chemicals (EDCs) in context with ecological scenarios.

These reports and associated concerns regarding the ubiquitous presences of EDCs in the environment have sparked both scientific and political debates regarding the need for strategies to assess and regulate chemicals with endocrine disrupting (ED) properties to protect human and environmental health. To address these needs, a number of countries, multinational governments such as the European Union and inter-government organizations (Organization for Economic Cooperation and Development, OECD) have initiated or amended programs to integrate EDCs into current strategies to assess chemical safety. These programs include the Endocrine Disruptor Screening Program (EDSP) of the US Environmental Protection Agency (US-EPA), the Strategic Programs on Endocrine Disruptors (SPEED) of the Japan Environment Agency, and the Joint Working Group on Endocrine Disrupters Testing and Assessment (EDTA) sponsored by the OECD.
While there is an increasing number of national and international strategies and policies that aim to address the phenomenon of endocrine disruption (ED) in context with chemical risk assessment, no comparable efforts to streamline and regulate exposure to EDCs in the environment have been made, and to date no separate water quality criteria or comparable environmental standards exist. However, according to the European Commission, the issue of endocrine disrupters will be addressed specifically in the context of the Water Framework Directive (WFD) that identifies "Substances and preparations, or the breakdown products of such, which have been proved to possess carcinogenic or mutagenic properties or properties which may affect steroidogenic, thyroid, reproduction or other endocrine-related functions in or via the aquatic environment" in its "Indicative List of the Main Pollutants" of concern (European Commission 2000) [8].

\section{Current national and international EDC screening programs and strategies}

\section{U.S. EPA - EDSP}

One of the leading and first nationally, legally-binding programs was the EDSP of the U.S. EPA, which employs a battery of in vitro and in vivo screening assays to assess the ED potential of a chemical. Specifically, the U.S. Congress included a provision in the Food Quality Protection Act of 1996 adding section 408 to the Federal Food, Drug, and Cosmetic Act (FFDCA). This section of the FFDCA requires EPA to "... develop a screening program, using appropriate validated test systems and other scientifically relevant information, to determine whether certain substances may have an effect in humans that is similar to an effect produced by a naturally occurring estrogen, or other such endocrine effect as the Administrator may designate [[21] U.S.C. 346 (p)]". Subsequent to passage of the Act, EPA formed the Endocrine Disruptor Screening and Testing Advisory Committee (EDSTAC) [9], a committee of scientists and stakeholders that was charged with the duty to provide EPA with recommendations on how to implement its EDSP. Upon recommendations from EDSTAC, the EDSP was expanded using the administrator's discretionary authority to include the androgen and thyroid hormone systems and wildlife effects as well as the originally mandated effects relating to estrogen. EPA accepted the EDSTAC's recommendations for a twotier screening program [9]. The focus of this two-tiered program has been first to develop in vitro and in vivo assays to identify and classify substances relative to their potential interaction with endocrine systems (Tier 1) and then to develop concentration-response relationships in animal models (Tier 2). 
Table 1 US-EPA's tier 1 Battery, and modes of action detected

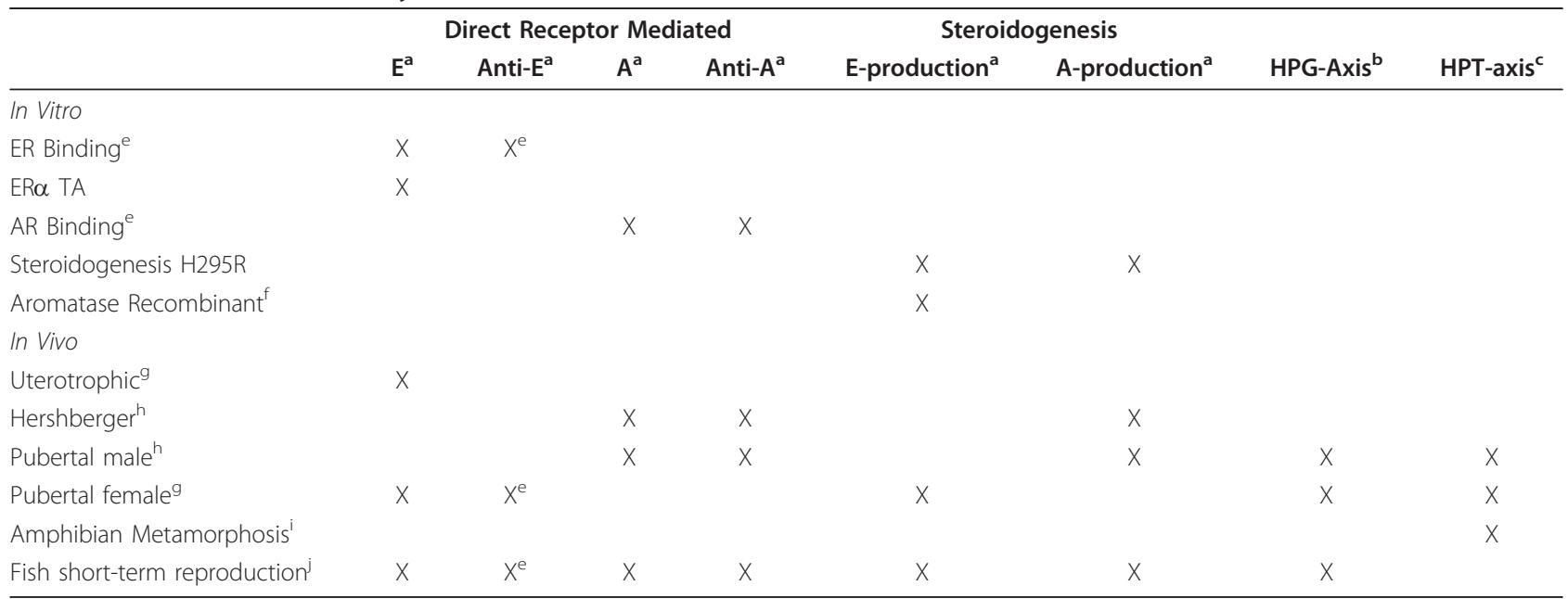

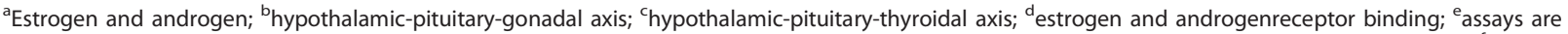
expected to detect anti-estrogens, but this was not established during the validation process since no estrogen receptor antagonists were tested; ${ }^{f}$ recombinant aromatase assay; ${ }^{9}$ female rat; ${ }^{h}$ male rat; ${ }^{i}$ amphibian metamorphosis assay; ${ }^{j}$ reproduction test with male and female fish. Modified after http://www.epa.gov/endo/ pubs/assayvalidation/tier1battery.htm.

\section{EDSP Tier 1 battery}

The EDSP Tier 1 battery was designed to work as a whole to allow detection of estrogen- and androgen-mediated effects by various modes of action including receptor binding (agonist and antagonist) and transcriptional activation, steroidogenesis, and hypothalamic-pituitary-gonadal (HPG) feedback (Table 1). It is comprised of a combination of in vitro and in vivo assays that aim to complement one another in the battery to enable the identification of specific endocrine mechanisms of chemicals, and to relate this to a biological response in a whole organism. In addition, rodent and amphibian in vivo assays were selected for the proposed battery based on their capacity to detect direct and indirect effects on thyroid function (hypothalamic-pituitary-thyroidal, HPT, feedback). Thus, the robustness of the proposed battery is based on the strengths of each individual assay and their complementary nature within the battery to detect effects on the estrogen, androgen or thyroid hormonal systems (Table 1).

\section{EDSP Tier 2 battery}

Once a chemical is identified as a potential EDC during Tier 1 screening, EPA will require further testing in a second tier. The purpose of this Tier 2 testing is to identify further and characterize chemical-induced interactions with estrogen, androgen, or thyroid hormonal systems for risk assessment. To date, no definite decisions have been made regarding the specific tests to be included into the Tier 2 testing stage. It is anticipated, however, that Tier 2 testing will focus on multi-generation testing with a broad range of taxa. Candidate assays for Tier 2 testing include amphibian-, bird-, and mammalian-two-generation tests, as well as a fish- and invertebrate(mysid)-life-cycle assay.
The US-EPA has started implementing its policies regarding EDC testing. In 2009, it has sent out the first test orders to industry requiring testing of 67 chemicals using the Tier 1 test battery. On November 17, 2010, the second list of chemicals for Tier 1 screening has been published. This list includes 134 chemicals and substances that have been listed as priorities within EPA's drinking water and pesticides programs.

One of the greatest challenges of the EDSP is the current lack of clear decision strategies and processes, or in other words: what happens if a chemical is flagged as a potential EDC during Tier 1 screening? While in theory flagging a chemical during Tier 1 would trigger confirmatory Tier 2 testing, it is unclear how and when this will happen as candidate test guidelines for Tier 2 are still under validation. Similarly, it is unclear what the decision process for removing or limiting the use of chemicals that tested positive will be. In conclusion, while there has been some progress made regarding the regulation of EDCs in the U.S.A. there is still a great deal of uncertainty and lack of clear policies and available tools that would allow moving a chemical smoothly through the complete EDSP process.

\section{Japan}

Japan has been among the first nations to address the issue of ED on a national level. In 1997 the Environmental Agency of Japan initiated an "Exogenous Endocrine Disrupting Chemical Task Force" under Tsuguyoshi Suzuki, which aimed to collect, review, and organize scientific information available on the phenomenon of ED. In 1998, the Japan Environment Agency 
has started the SPEED initiative. The agencies policies set forth in SPEED included:

1. Promotion of field investigations into the present state of environmental pollution and of adverse effects on wildlife of endocrine disrupting chemicals;

2. Promotion of research and screening and testing method development;

3. Promotion of environmental risk assessment, risk management, and information dissemination; and 4. Strengthening of international networks.

Since then, Japan has been a strong supporter of national research activities in the field of EDC. It has supported a great deal of research in the field, and has been actively involved in international initiatives such as the Joint Working Group on EDTA sponsored by the Organization for Economic Cooperation and Development (OECD). Furthermore, the Ministry of Environment of Japan has worked together with the WHO/ UNEP/ILO International Programme on Chemical Safety to host a joint workshop on "Endocrine Disruptors: Research Needs and Future Directions" in Tokyo. Based on the outcome of this workshop, a final report has been published [10]. The report summarized the current state-of-the-science in field of endocrine disruption, and identified key data gaps in that research area.

\section{European Union}

To date, no mandatory testing programs such as U.S. EPA's EDSP exist in Europe. However, the EU has acknowledged the phenomenon of ED as a priority area, and has developed short, medium and long-term strategies to address this issue:

\section{Short-term strategy}

The short-term strategy of the EU as identified in the European Commission's Communication [11] was to establish a priority list of candidate substances for further evaluation of their ED properties. Prioritization was to be conducted by an independent review of the current state of knowledge regarding the endocrine disrupting effects of and exposure to these chemicals in humans and wildlife followed by consultation with stakeholders and the Commission's Scientific Committees. In 2007 the European Community published their third progress report on the implementation of the "Community Strategy for Endocrine Disrupters", summarizing the findings on the review of scientific information for prioritizing of chemicals (European Commission 2007) [12]. In total, 575 substances were investigated as to their ED effects. In terms of prioritization, it was found that, out of this number, 320 substances showed evidence or potential evidence for ED effects, while in total, 109 substances were not retained in the priority list, either due to insufficient data on ED effects or insufficient scientific evidence. One hundred and fortyseven substances have been excluded from the evaluation during the process as they were identified as double entries, mixtures or of doubtful relevance.

An assessment of the legal status of the substances with evidence or potential evidence of endocrine disrupting effects showed, that the majority of them are already subject to a ban or restriction or are addressed under existing Community legislation, although for reasons not necessarily related to endocrine disruption.

Furthermore, short-term strategies included communication to public and cooperation with other government programs including Japan and the USA, and international efforts including the $\mathrm{WHO}$ and OECD regarding EDCs. The European Commission and the World Health Organisation (WHO) have since co-operated, through the International Programme for Chemical Safety, on the maintenance of a global research inventory, which is housed at the Commission's Joint Research Centre and on the compilation of a "Global state-of-the-science of endocrine disruptors" report (WHO 2002) [13]. The European Commission is actively involved the efforts of the OECD to develop agreed test methods for endocrine disrupters.

In 2000, the European Commission and United States Environmental Protection Agency agreed to share information on a regular basis on priority setting, screening and testing as well as on research activities.

\section{Medium-term strategy}

Issues identified by the EU included the lack of understanding of the specific modes of action of potential EDCs (most of the focus has been on estrogen (ER) and androgen (AR) receptor agonists), the biological relevance of many of the effects described at the biochemical or molecular level, as well as the impact on humans and wildlife. Also, there was the lack of appropriate test methods and testing strategies to reliable assess the ED potential of a substance, and of models that enable estimating exposure to EDCs. Therefore, the European Commission has made funding of research linked to ED a priority for their fifth, sixth and seventh Framework Programmes. Since the implementation of these framework programs, the EU has funded a large number (over 80) of research projects as part of their fifth, sixth and seventh Framework Programmes including studies in the area of human and wildlife health, development of test methods, strategies, and risks assessment tools (Table 2; http://ec.europa.eu/research/endocrine/). Furthermore, the European Commission has worked closely with its member states to coordinate the EU input into the OECD EDTA to develop internationally harmonized test methods and testing strategies for EDCs. Many of these efforts are still ongoing. 
Table 2 Projects funded during the fourth through seventh Framework Programmes of the European Comission and their area of research and completion status

\begin{tabular}{|c|c|c|c|c|}
\hline \multirow[t]{2}{*}{ Research area } & \multirow[t]{2}{*}{ Project names } & \multirow{2}{*}{$\begin{array}{l}\text { Time- } \\
\text { period }\end{array}$} & \multicolumn{2}{|c|}{ Status } \\
\hline & & & Completed & Ongoing \\
\hline \multicolumn{5}{|l|}{$4^{\text {th }}$ Framework Programme } \\
\hline Aquatic wildlife and birds (5) & $\begin{array}{l}\text { POP-REP; IDEA; EES AND FISH REPRODUCTION; COMPREHEND; } \\
\text { No Name }\end{array}$ & $\begin{array}{l}1997- \\
2002\end{array}$ & $x$ & \\
\hline EDC effects in humans/mammals (6) & $\begin{array}{l}\text { DIOXIN RISK ASSESSMENT; RENCO; No Name; No Name; No } \\
\text { Name; No Name }\end{array}$ & $\begin{array}{l}1996- \\
2002\end{array}$ & $x$ & \\
\hline Other projects (3) & No Name; PRENDISENSOR; SANDRINE; EDAEP & $\begin{array}{l}1997- \\
2002\end{array}$ & $x$ & \\
\hline \multicolumn{5}{|l|}{$5^{\text {th }}$ Framework Programme } \\
\hline Aquatic wildlife (5) & ACE; BEEP; BIOCET; COMPRENDO; FAMIZ & $\begin{array}{l}2000- \\
2005\end{array}$ & $x$ & \\
\hline Effects on bones (1) & BONETOX & $\begin{array}{l}2003- \\
2006\end{array}$ & $x$ & \\
\hline $\begin{array}{l}\text { Multi-organ effects of EDCs and risk assessment } \\
\text { (8) }\end{array}$ & $\begin{array}{l}\text { COMPARE; DIOXIN RISK ASSESSMENT; EDEN; EURISKED; } \\
\text { EMNDOMET; ESTROGENS AND DISEASE; FIRE; PCBRISK }\end{array}$ & $\begin{array}{l}2000- \\
2006\end{array}$ & $x$ & \\
\hline Neurodevelopmental/endocrine effects (3) & ANEMONE; PBDE-NTOX; SENSPESTI & $2000-$ & $x$ & \\
\hline Phytoestrogens (2) & PHYTO-PREVENT; PHYTOS & $\begin{array}{l}2001- \\
2004\end{array}$ & $x$ & \\
\hline Reproductive health outcomes (5) & $\begin{array}{l}\text { ENDISRUPT; ENVIRON. REPROD. HEALTH; EXPORED; GENDISRUPT; } \\
\text { INUENDO; }\end{array}$ & $2000-$ & $x$ & \\
\hline $\begin{array}{l}\text { Development of test methods and } \\
\text { technologies (4) }\end{array}$ & EASYRING; EDERA; MENDOS; POSEIDON & $\begin{array}{l}2001- \\
2005\end{array}$ & $x$ & \\
\hline \multicolumn{5}{|l|}{$6^{\text {th }}$ Framework Programme } \\
\hline $\begin{array}{l}\text { Mechanism of action of EDCs and toxicology } \\
\text { (2) }\end{array}$ & ATHON; CASCADE & $\begin{array}{l}2004- \\
2010\end{array}$ & $x$ & \\
\hline Risk assessment methods and tools (5) & CEASAR; ESBIO; NOMIRACLE; NORMAN; SAFE FOODS & $\begin{array}{l}2004- \\
2009\end{array}$ & $x$ & \\
\hline Reproductive health outcomes (3) & F\&F; PIONEER; REPROTECT & $\begin{array}{l}2004- \\
2009\end{array}$ & $x$ & \\
\hline Neurodevelopmental effects and aging (2) & DEVNERTOX; CRESCENDO & $\begin{array}{l}2003- \\
2011\end{array}$ & $x$ & $x$ \\
\hline Review of state-of-the-art (1) & HENVINET & $2006-$ & & $x$ \\
\hline Development of in vitro technologies (1) & BIOCOP & $\begin{array}{l}2005- \\
2010\end{array}$ & & $x$ \\
\hline Environmental causes of cancer (1) & NEWGENERIS & $2006-$ & & $x$ \\
\hline Food and feed chain (1) & AQUAMAX & $2006-$ & & $x$ \\
\hline $\begin{array}{l}\text { Risk analysis of chemicals and other stressors } \\
\text { (2) }\end{array}$ & INTARESE; PHIME & $\begin{array}{l}2005- \\
2011\end{array}$ & & $x$ \\
\hline \multicolumn{5}{|l|}{$7^{\text {th }}$ Framework Programme } \\
\hline Detection of contaminants (1) & CONFIDENCE & $\begin{array}{l}2008- \\
2012\end{array}$ & & $x$ \\
\hline $\begin{array}{l}\text { Improvement of risk assessment models, } \\
\text { methods, tools and management (11) }\end{array}$ & $\begin{array}{l}\text { ARCRISK; CADASTER; COPHES; ENFIRO; ENRIECO; ENVIROGENO } \\
\text { MARKERS; FACET; OPENTOX; PERFOOD; RISKCYCLE; SYSTEQ }\end{array}$ & $\begin{array}{l}2008- \\
2013\end{array}$ & & $x$ \\
\hline Reproductive health outcomes (4) & NECTAR; CONTAMED; DEER; REEF & $\begin{array}{l}2008- \\
2013\end{array}$ & & $x$ \\
\hline Metabolic disorders (1) & OBELIX & $\begin{array}{l}2009- \\
2013\end{array}$ & & $x$ \\
\hline Others (2) & CLEAR; ESCAPE & $\begin{array}{l}2008- \\
2013\end{array}$ & & $x$ \\
\hline
\end{tabular}

Number in brackets: number of projects funded in this research area 


\section{Long-term strategy}

Long-term strategies of the EU are on the development and adaptation of legislative instruments and policy action that enable hazard identification, risk assessment and risk management of EDCs. Specifically, current initiatives such as Registration, Evaluation, Authorisation and Restriction of Chemicals (REACH) and Environment and Health Strategy (SCALE) shall serve as legislative frameworks in support of the regulation of EDCs. Relevant recent developments were the adoption of regulation $1907 / 2006$ (REACH), formally adopted on 18 December 2006, the proposal for a directive setting environmental quality standards for priority substances under the water framework directive (2006) or the new pesticide regulation 1107/2009 EEC [14,15] (to be applied in the European Union from 14 June 2011). Specifically, REACH requires an authorization (and/or replacement by suitable alternative substances or technologies) for substances with endocrine disrupting properties, for which there is scientific evidence of probable serious effects to human health or the environment which give rise to an equivalent level of concern as CMR-substances (carcinogens, mutagens, toxic for reproduction - the two highest categories each), PBT-substances (persistent, bioaccumulative and toxic) and vPvB substances (very persistent and very bioaccumulative). For pesticides with similar properties as these so-called REACH-SVCHs (substances of very high concern according to $\mathrm{REACH}$ article 57) no authorization shall be granted according to the new Regulation (EC) No 1107/2009. Regarding wildlife, the new "endocrine cut-off criterion" states: "An active substance, safener or synergist shall only be approved if, on the basis of the assessment of Community or internationally agreed test guidelines, it is not considered to have endocrine disrupting properties that may cause adverse effects on nontarget organisms unless the exposure of non-target organisms to that active substance in a plant protection product under realistic proposed conditions of use is negligible" (EC 1107/2009, Annex II, 3.8.2). Thus, a paradigm shift in regulatory decision making was introduced for pesticides with endocrine properties: Instead of the established risk-based approach, a hazard-based approach is now required (i.e. only the proven presence or assumed absence of endocrine disrupting properties shall be decisive for a [non] authorization). However, specific scientific criteria to support regulatory decision making on substances with endocrine disrupting properties both under $\mathrm{REACH}$ and the new pesticide regulation are lacking today and thus have to be developed and agreed upon (at least in the EU) within the near future.

\section{Oecd}

Recognizing the global relevance of the issue of endocrine disruption, in addition to the US-EPA activities, the OECD initiated a high-priority activity in 1998 to revise existing, and to develop new test guidelines for the screening and testing of potential endocrine disrupting chemicals. The OECD conceptual framework for testing and assessment of potential endocrine disrupting chemicals comprises five levels, each level corresponding to a different level of biological complexity (OECD 2002) [16]. The framework was developed in consultation with member countries. Proposed testing schemes were developed at critical workshops (i.e. the European Workshop on the Impact of Endocrine Disrupters on Human Health and Wildlife [Weybridge Workshop] and the Joint SETAC (Society of Environmental Toxicology and Chemistry) Europe/OECD/EC Expert Workshop on Endocrine Modulators and Wildlife: Assessment and Testing [EMWAT Workshop]), other national activities such as US-EPA's EDSTAC and research activities in Japan, and industry initiatives. Since its initial establishment, the framework has been revised to its current form (Figure 1). It has to be noted that the conceptual framework developed by the EDTA does not represent a testing scheme but rather a tool box in which the various tests that can contribute information for the detection of the hazards of endocrine disruption are placed. It is organized into five levels each corresponding to a different level of biological complexity (for both toxicological and ecotoxicological areas). The format of this tool box is flexible, and it allows for assays and tests to be added as deemed necessary based on new insights or developments.

\section{Drinking water, effluent and environmental analysis and monitoring EDCs in drinking water}

As a part of the comprehensive review paper 'Endocrine Disruptors and Water Quality: A State-of-the-Art Review' by Burkhardt-Holm [17], the author investigated the question whether drinking water could be a source for the exposure of people to EDCs? The presence of estrogenic chemicals in drinking water was reported from several researchers from various countries (e.g. [18]). Endocrine potentials of drinking water were shown to be related to several substances that were detected in Ground water. Recently, the joined BMBF research project HoT [[19,20] and Wölz J, Grosshans K, Streck G, Schulze T, Rastall A, Erdinger L, Brack W, Fleig M, Kühlers D, Braunbeck T, Hollert H: Estrogen receptor mediated activity in bankside groundwater, with flood suspended particulate matter and floodplain soil - An approach combining tracer substance, bioassay and target analysis, submitted] funded by the German Ministry for Education BMBF demonstrated that contaminated suspended particulate matter from the Rhine river has the potential to influence drinking water 


\section{OECD Conceptual Framework for the Testing and Assessment of Endocrine Disrupting Chemicals}

Note: Document prepared by the Secretariat of the Test Guidelines Programme based on the agreement reached at the 6th Meeting of the EDTA Task Force

\begin{tabular}{|c|c|}
\hline $\begin{array}{l}\text { Level } 1 \\
\text { Sorting \& prioritization based } \\
\text { upon existing information }\end{array}$ & $\begin{array}{l}\text {-Physical \& chemical properties, e.g., MW, reactivity, volatility, biodegradability } \\
\text {-Human \& environmental exposure, e.g., production volume, release, use patterns } \\
\text {-Hazard, e.g., available toxicological data }\end{array}$ \\
\hline $\begin{array}{l}\text { Level } 2 \\
\text { In vitro assays providing } \\
\text { mechanistic data }\end{array}$ & $\begin{array}{ll}\cdot \text { ER, AR, TR receptor binding affinity } & \bullet \text { High Through Put Prescreens } \\
\text {-Transcriptional activation } & \bullet \text { Thyroid function } \\
\text {-Aromatase \& Steroidogenesis in vitro } & \bullet \text { Fish hepatocyte VTG assay } \\
\text {-Aryl hydrocarbon receptor recognition/binding } & \cdot \text { OSARs; Others (as appropriate) } \\
\end{array}$ \\
\hline $\begin{array}{l}\text { Level } 3 \\
\text { In vivo assays providing data about single } \\
\text { endocrine Mechanisms and effects }\end{array}$ & $\begin{array}{l}\text { - Uterotrophic Assay (estrogenic related) } \\
\text { - Hershberger Assay (androgenic related) } \\
\text { - Non-receptor mediated hormone function }\end{array}$ \\
\hline $\begin{array}{l}\text { Level } 4 \\
\text { In vivo assays providing data } \\
\text { about multiple endocrine } \\
\text { mechanisms and effects }\end{array}$ & $\begin{array}{l}\text { - Enhanced OECD } 407 \text { (endpoints based } \\
\text { on endocrine mechanisms) } \\
\text { - Male and female pubertal assays } \\
\text {-Adult intact male assay }\end{array}$ \\
\hline $\begin{array}{l}\text { Level } \mathbf{5} \\
\text { In vivo assays providing data on effects } \\
\text { from endocrine \& other mechanisms }\end{array}$ & $\begin{array}{ll}\text {-1-generation assay (TG415 enhanced) } & \text { •Partial and full life cycle assays in fish, } \\
\text {-2-generation assay (TG416 enhanced) } & \text { birds, amphibians \& invertebrates } \\
\text { - Reproductive screening (TG421 enhanced) } & \text { (development \& reproduction) } \\
\text { - Combined } 28 \text { day/reproduction screening test (TG } 422 \text { enhanced) }\end{array}$ \\
\hline
\end{tabular}

Figure 1 OECD conceptual framework. OECD conceptual framework for the testing and assessment of endocrine disrupting chemicals in accordance with the consensus reached during the $6^{\text {th }}$ meeting of the EDTA Task Force. (Adapted from OECD 2002 [16]).

recourses in floodplains and nearby areas used for drinking water supply.

As shown by Pinto and Reali [21] and Wagner and Oehlmann [22] mineral water bottled in polyethylene terephthalate (PET) and water in glass bottles or even tap water had some weak endocrine activity. For example, additives such as bisphenol A that are used as plasticizers in some packaging material were shown to leach into the water. Seventy-eight percent of all samples from PET bottles bought in Germany showed estrogenic potentials with concentration equivalents of up to $75 \mathrm{ng}$ $17 \beta$-estradiol/L [22]. In Italy, $10 \%$ of the investigated samples showed estrogenic activity, with maximum concentration equivalents of $23 \mathrm{ng} 17 \beta$-estradiol/L. Although a endocrine effectiveness was shown in a couple of independent studies, a legislation specific for endocrine disruptors is not in action in the European Community to date [17]. However, due to increasing public pressure and concerns, a few countries started taking action regarding the regulation of EDCs associated with food containers. For example, in September 2010, Canada became the first country to declare BPA as a toxic substance and banned its use in certain applications such as baby bottles [23]. In 2010, the European Union announced that it will follow Canada's example ban the use of bisphenol A in baby bottles effective in 2011 http://www.reuters.com/article/2010/ 11/25/us-eu-health-plastic-idUSTRE6AO3MS20101125.

\section{Environmental sources and exposure to EDCs}

A number of studies have been conducted to characterize the endocrine potential of municipal effluents $[24,25]$, surface water [26-28] and sediments $[26,27,29,30]$, and there has been increasing awareness of the need for testing approaches targeting EDCs to be included into current environmental assessments and monitoring [31-36].

However, while there have been multiple efforts at the national and international level to develop testing and regulatory approaches EDCs in context with chemical risk assessment, no such efforts have been undertaken in context with environmental risk assessments, effluent testing and the evaluation of drinking water safety and agricultural practices. For example, programs such as the European WFD (EC 2000/60/EG) or the US Clean Water Act do not explicitly test for EDCs, and 
considering the unique requirements and endpoints required to assess the endocrine potential of a sample, these programs are unlikely to appropriately address exposure to these chemicals. This is of great concern since recent studies revealed the relevance EDCs may have in aquatic ecosystem. For example, Kidd et al. [7] demonstrated declines in populations of certain fish species after exposure to environmentally relevant concentrations of the synthetic estrogen ethinylestradiol in whole lake experiments. Additionally, various studies demonstrated the potential of sediment-bound EDCs to cause adverse effects in aquatic wildlife using different in vitro and in vivo assays [26,27,29,30,37-39].

Recent studies predicted that the objective of the WFD to achieve good ecological/chemical status by 2015 is likely to fail in many European catchment areas because of the continuing remobilization of sedimentbound pollutants in heavily contaminated old sediments [40-42]. As shown by several sediment toxicity studies using mass balance calculation approaches and effect directed analyses (for review see Hollert et al. [26] and Brack et al., [32]), known endocrine active chemicals such as bisphenol A and alkylphenols typically only explain approximately $10 \%$ to $15 \%$ of the entire endocrine potential in aquatic systems but tend to contribute at greater proportions to ED potential of particle-related effects. Remobilization of sediments during flood events is therefore of greatest relevance for the mass balance of BPA and alkylphenols in rivers [43] (Figure 2). As a consequence, in support of the assessments of risk and fulfillment of regulatory needs there is need for EDA driven studies identifying the large proportion of unknown EDCs in river water and sediments.

\section{Wastewater treatment plants}

One of most important sources for EDCs are the effluent from sewage treatment plants. These facilities often do not eliminate micropollutants completely, and thus, are important point sources for these substances. In particular, concerns about EDCs in wastewater treatment plants effluents stimulated the implementation of advanced treatment steps for the elimination of trace organic contaminants [44]. Estrogenically active compounds like $17 \beta$-estradiol and $17 \alpha$-ethinylestradiol, for example, are removed by $99.9 \%$ and $78 \%$, respectively, with conventional wastewater treatment systems [45]. Elimination strongly depends on the treatment steps (primary, secondary and tertiary), aerobic conditions, temperatures, etc., and under certain conditions (e.g. low temperature, no nitrification step) there are significant concentrations of endocrine active chemicals such as estrogens remaining in the treated effluent that is released into the receiving water body $[45,46]$. Under conditions such as occur in some U.K. rivers that have very great sewage loads (often greater 25\% up to greater $80 \%$ ), remaining concentrations of estrogenic compounds have been show to lead to adverse effects including reproductive disturbances in wild fish populations [47]. Recently, in Europe, there is increasing pressure to further develop advanced wastewater treatment methods, such as ozonation and activated carbon treatment for a broad application in municipal wastewater treatment $[34,48]$. As a consequence, there are a number of projects that have been initiated during recent years to implement and evaluate the efficiency of these additional treatment steps regarding their potential to remove endocrine active substances. Examples are the "Strategy MICROPOLL"of the Federal Office for the Environment in Switzerland and a series of projects supported by the MUNLV (Ministry for Climate Protection, Environment, Agriculture, Nature Conservation and Consumer Protection of the German State of North Rhine-Westphalia). One of the key challenges arising in context with these projects is the availability of reliable and effective tools to assess the elimination efficiency of the additional treatment steps. Given the complex nature of chemicals with endocrine-disrupting properties as well as the likelihood of a large number of yet unknown EDCs that are present in sewage effluent it would not only be prohibitively expensive but also virtually impossible to analytically identify all of these chemicals due to detection limits in the available analytical methodologies. Therefore, there is an increasing trend towards the use of bio-analytical techniques that allow detecting specific groups of chemicals based on their common properties to interact with specific biological processes/ pathways [31]. Accordingly, such bio-analytical tools are increasingly used in the above-described projects for identifying the most efficient elimination method. Preliminary biotest data obtained by means of in vitro tests such as the ER-CALUX, and the L-YES/YAS revealed the effective removal of estrogenic activity by ozonation [49-51]. In contrast, ozonation resulted only in a minor attenuation of the toxic effects as detected after exposure of rainbow trout (Oncorhynchus mykiss) and steroidogenic active cells to effluent when using the fish early life stage toxicity test [44] and the H295R-Assay [49-51], respectively. As shown by Stalter et al. [44] the combination of ozonation and sand filtration is suitable to prevent from adverse ecotoxicological effects of ozonation. Additionally, in the Lausanne pilot study of the strategy MICROPOLL project a stronger amelioration of toxic effects as well as a strong reduction in the induction of plasma vitellogenin concentrations in male fish was observed after advanced wastewater treatment [52]. This is in accordance to the study of Nakada et al. [53] that demonstrated that a combination of ozonation, sand filtration and activated sludge treatment gives the 

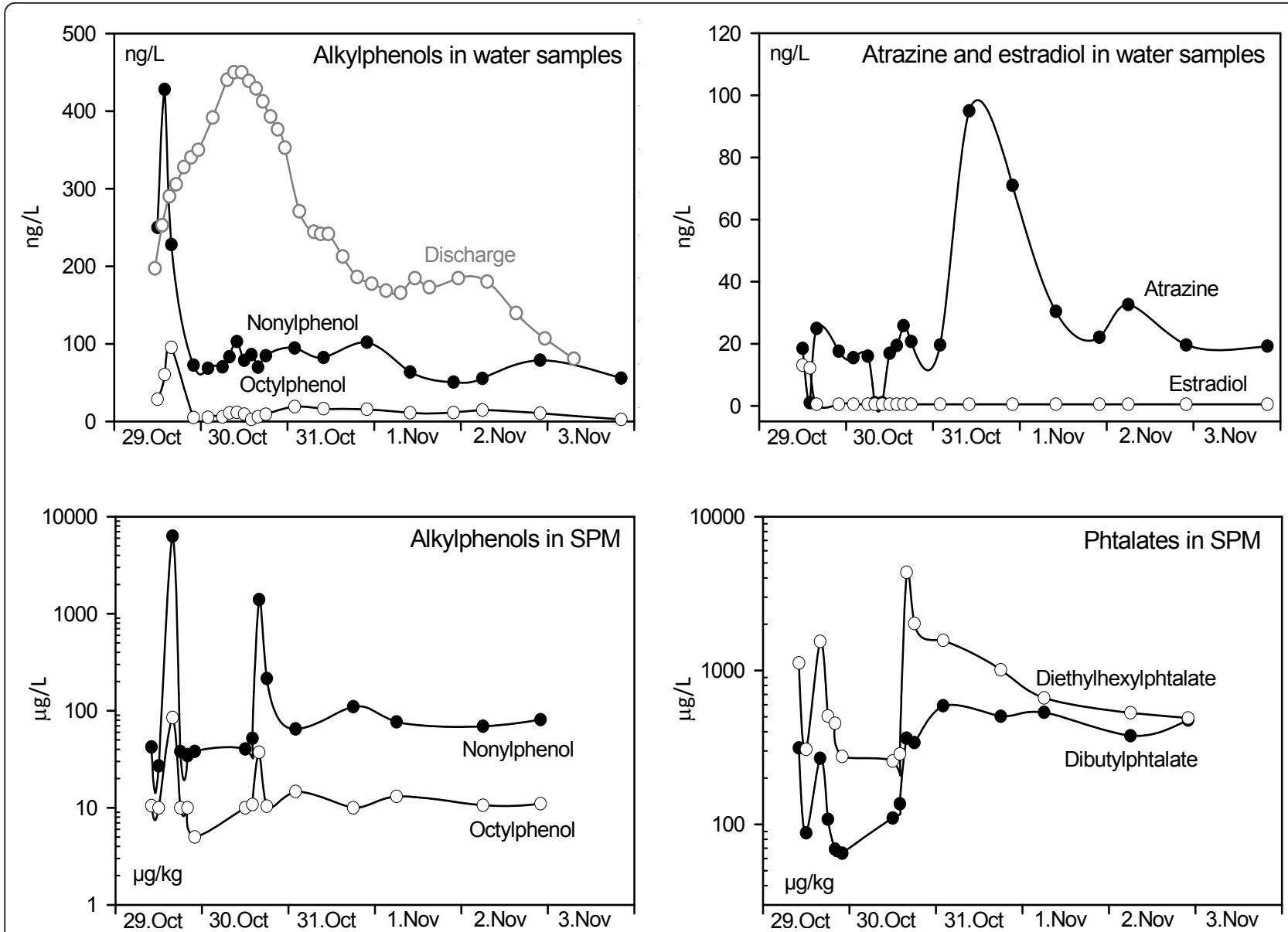

Figure 2 Concentrations of suspected endocrine active substances and suspended particulate matter. Concentrations of suspected endocrine active substances in water samples and suspended particulate matter during a flood event (River Neckar, Heidelberg, in November/ December 1998). The discharge of the flood event is given without dimension and should elucidate that during the maximum of a given flood event greatest concentrations of alkylphenols can be observed (data Holtey Weber, redrawn according to Hollert 2001 [43]).

best removal result for EDCs. To remove EDCs in the drinking water treatment process, granular activated carbon has been identified as the preferable method to be used (US-EPA 2001; [17,54]).

\section{Testing and screening approaches and tool boxes}

Recently, the Global Water Research Coalition (GWRC) conducted an inter-lab comparison study in order to evaluate the performance of five in vitro bioassays, including yeast estrogen screen (YES), ERCALUX, MELN, T47D-KBluc and E-Screen assays to assess estrogenic activity in a variety of water matrices http://www.edctoolbox.info, [55]. The study concluded that some bioassay techniques are now sufficiently advanced that they can be used either as a cost-effective first-pass detection system or in combination with standard analytical methods to measure estrogenic pollutants in environmental waters. However, standardization of bioassay data analysis was identified as a crucial step forward towards accurate bioassay-derived estrogenicity measurements.

Recently, Kase et al. [56] published an extensive literature review survey aiming to give an overview and an evaluation on available and validated biological test systems for the detection of endocrine disruptive and reproductive effects in aquatic systems for monitoring purposes. Based on the review and an international workshop organized by the Swiss Centre for Applied Ecotoxicology of Eawag/EPFL (Ecotox Centre, Duebendorf, Switzerland) a recommendation for a modular ecotoxicological test platform was given. The study focused on test methods for sex hormonal active substances but also considered alternative MOAs such as effects on hormone production. On the basis of the literature search and ongoing international validation efforts by the OECD for methods to detect endocrine disruptive effects, 15 biological test methods (five in vivo and ten in vitro) were selected including eight OECD methods 


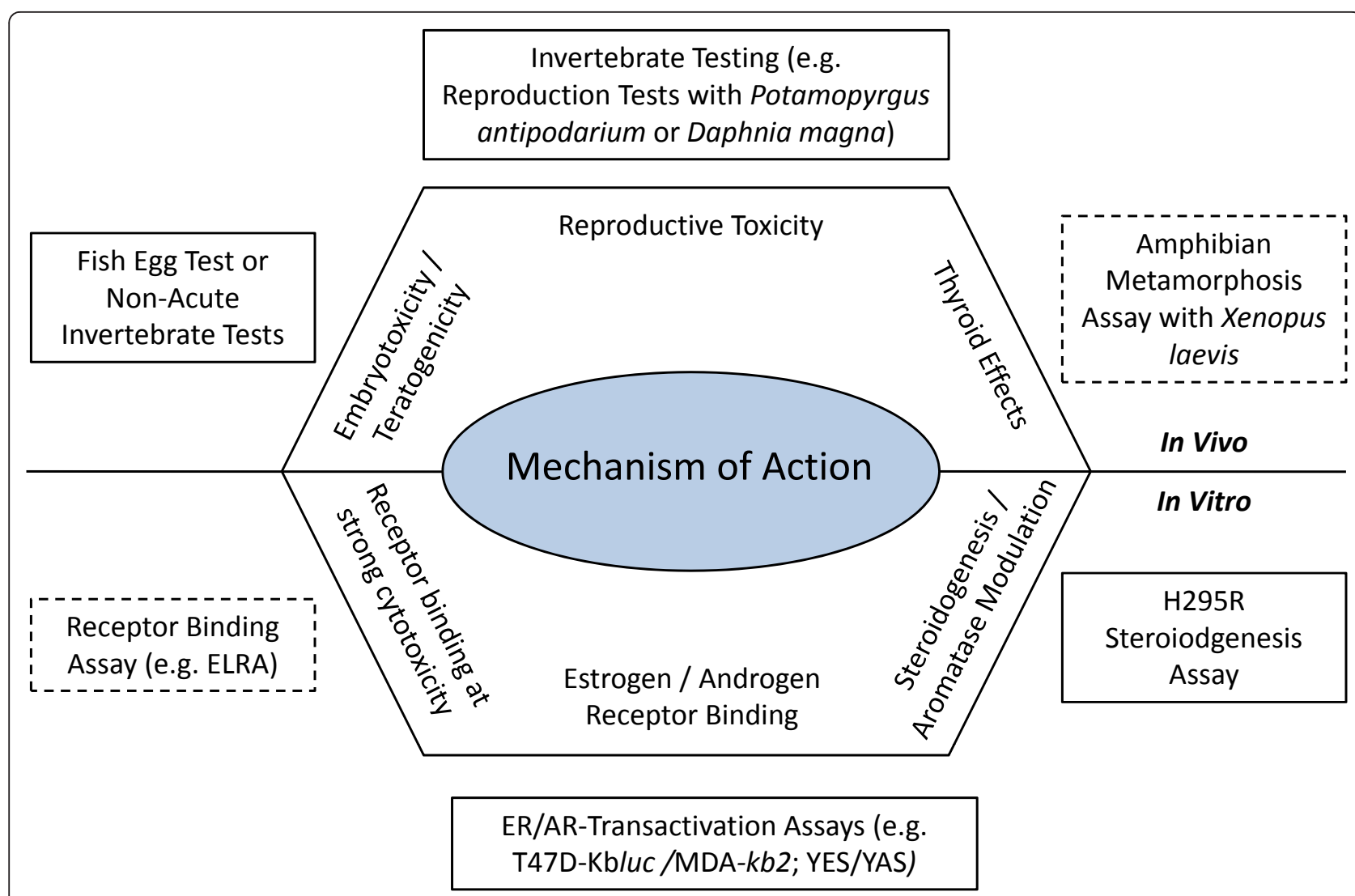

Figure 3 Proposed modular test platform. To identify and assess the endocrine potential of environmental samples using a combination of in vivo and in vivo bioassays. Dotted boxes refer to optional tests (redrawn and adapted from Kase et al. [56]).

and three out of five in vitro methods mentioned in the Global Water Research Coalition (GWRC) report. Kase et al. [56] further recommend a testing strategy based on their review to assess the ecotoxicological relevance of EDCs (Figure 3). The applicability for testing and screening of environmental samples regarding their endocrine disrupting properties is currently tested in a joint project coordinated by the Ecotox Centre. http:// www.oekotoxzentrum.ch/projekte/micropolleffektbewertung/index

\section{Current issues and uncertainties}

There has been a great deal of progress over the past decade to address scientific uncertainties and regulatory needs concerning EDCs. A large number of national and international programs have been initiated, and efforts have been made to harmonize testing methods in context with chemical risks assessment of EDCs. However, there are still a number of remaining concerns and uncertainties.

\section{Alternatives to animal testing}

One of the key issues remaining in context with the globally increasing number of testing programs to assess the potential of chemicals to disrupt endocrine functions is the reliance on a large number of in vivo tests using live animals. With increasing testing demands and requirements the number of rats, mice, fish and frogs needed to fulfill these will grow proportionally. For example, subjecting a single chemical to the complete Tier 1 testing battery of US-EPA's EDSP would require approximately 130 rats, 30 tadpoles/froglets and 60 fish. Considering the vast amount of chemicals ultimatively to be tested (approximately 80,000) this would result in the sacrifice of millions of animals. This represents both an ethical and economical problem. To reduce the number of test animals, therefore, programs such as the EDSP have made increasingly attempts to include in vitro methodologies that are based on stable cells lines or sub-cellular compartments and modeling approaches (e.g. QSAR) in their testing scheme where possible. Similar trends are observed in other parts of the world such as Europe, and international organization such as the OECD are promoting the use of alternative testing methods through groups such as the Non Animal Testing Validation and Management Group.

While these efforts are promising, there is still a great deal of uncertainty regarding the use of in vitro tests as 
a replacement of in vivo assays. Specifically, there is a lack of understanding of the relevance of results obtained by means of in vitro assays to whole organisms. In vitro systems often represent highly simplified and/or artificial (e.g. yeast cells transfected with a human receptor) systems that lack the complexity of an organism with its feedback loops, cross-talk between different biological pathways, metabolism, etc. There have been a few studies in the past that compared in vitro with in vivo data, and which have produced ambiguous results (e.g. $[57,58])$. In general, however, our understanding of the biological pathways currently used in vitro assays are "equipped" with is rather limited, and there is need for additional studies specifically designed to address these uncertainties. Similarly, many in vitro but also some in vivo assays make decisions based on effects that are measured at the sub-organismal (molecular, sub-cellular or cellular) level. What is often lacking, though, is the ability to link these endpoints with biological relevant responses [59]. Thus, one of the key future challenges is to align the primary mechanistic data obtained by means of genomic or other sub-organismal studies with outcomes of demographic relevance such as survival and reproduction. In fact, recent efforts are underway to align the mechanistic data obtained by means of genomic or other sub-organismal studies with apical endpoints that are required in risk assessment, and which have been termed adverse outcome pathways (AOPs; [60]). AOPs present a promising concept that aims to identify critical initiating molecular events that are specific to certain vital pathways. For example, vitellogenin (VTG; egg yolk protein) production by females is a prerequisite for successful egg production in egg-laying vertebrates, and inhibition of VTG synthesis has been successfully used as a predictor of decreased fecundity [60].

\section{Harmonization of testing methods and strategies}

Another main issue is the lack of streamlined and globally harmonized and accepted methodologies and procedures to assess ED properties of chemicals and environmental samples. In the chemical risk assessment scene the need for such harmonization efforts is increasingly recognized. As discussed above, this resulted in a number of efforts at the national and international level to develop and harmonize testing approaches and regulate EDCs. It should be recognized, however, that many of these efforts are still in their infancy, and that there is need for internationally recognized and harmonized science-based decision criteria that clearly enable the identification of EDCs and subsequent needs for regulating these substances. No such efforts have been undertaken in context with environmental risk assessment approaches, effluent testing and the evaluation of drinking water safety and agricultural practices. Furthermore, current environmental monitoring programs such as the European WFD primarily rely on chemical analytical data and do not consider effect-based ecotoxicological assessment. However, combined approaches using bioanalytical tools and chemical measurements have been shown to be powerful and promising tools for the identification of novel or unexpected toxicants causing adverse effects in biological systems. For example, natural estrogenic steroids together with the synthetic contraceptive pill component ethinylestradiol - originating primarily from wastewater treatment plants - have been identified by EDA as major estrogens in water samples and fish bile $[32,61,62]$. Based on these findings, these compounds moved into the focus of monitoring, risk assessment and technological improvements for wastewater treatment plants [32]. Ethinylestradiol is now listed as a candidate for European priority pollutants. This demonstrates the potential and relevance of concepts such as EDA or TIE (toxicity identification and evaluation) in support of current environmental monitoring strategies [31].

\section{Invertebrates}

As outlined above, recent reports have shown that a number of xenobiotics in the environment are capable of interfering with the normal endocrine function in a variety of animals. The overwhelming majority of the studies on the effects of hormone-mimetic industrial chemicals were focused on findings in vertebrates [63]. Although approximately $95 \%$ of known species in the animal kingdom are invertebrates, studies on the effects of EDCs on invertebrates are still scarce. According to the results of the SETAC workshop on Endocrine Disruption in Invertebrates, only $10 \%$ of these invertebrate studies were conducted with terrestrial invertebrates [64]. As stated by Oehlmann-Schulte and Oehlmann [63] the limited number of examples for EDCs in invertebrates is partially due to the fact that their hormonal systems are rather poorly understood in comparison with vertebrates. Recently, Lemons and coworkers [65] showed that both bisphenol A and vinclozolin disrupt the endocrine function of important representatives of soil edaphic invertebrates. In the study, enhanced mortality turned out to be the effect of incomplete ecdysis related to increased ecdysteroids titres. Lemons and coworkers [65] concluded therefore, that 'hyperecdysonism' might be a promising endpoint to detect and assess EDCs in arthropods inhabiting the terrestrial environment. Despite these few successful examples of potential methodologies to characterize and assess ED in invertebrates, there is still a great deal of uncertainty and lack of appropriate methods regarding the assessment of EDC effects in this group of organisms. In order to be able to establish relevant environmental monitoring and 
assessment programs for EDCs, however, it would be essential to include ED effects on invertebrates because they represent a critical aspect in the food-web of practically all ecosystems.

\section{Conclusions}

The past two decades have witnessed a significant increase in efforts to improve and harmonize strategies and approaches to assess the risks of EDCs to humans and the environment. Regulatory structures have been or are currently established in the USA, Japan and Europe, and the first mandatory testing program, the EDSP, has been implemented by the US-EPA. Through OECD's joint EDTA working group a global platform for the harmonization and general acceptance of tests to assess the potential of chemicals to interact with the endocrine system has been generated. The increasing requirements for testing and screening, however, have create new issues, and there are great concerns regarding the dramatic increase in use of live test organisms and huge costs associated with extensive testing. In response to these concerns, there is a growing demand for alternative testing strategies including priority setting, tiered screening, and the use of in silico systems and in vitro assays. However, many of these alternative approaches still require validation and/or calibration with regard to their predictive power and relevance for living organisms. Additional efforts to improve current risk assessment strategies for EDCs include the use of advance omic technologies to aid in identifying critical pathways and molecular endpoints that can be used to define AOPs that enable prediction of biological relevant effects. While there have been a great number of efforts in support of improving and streamlining chemical risk assessment for EDCs, similar efforts in context with environmental screening and risk assessments are still in their infancy. Moreover, programs such as the European WFD or the US Clean Water Act do not explicitly test for EDCs, and considering the unique requirements and endpoints required to assess the endocrine potential of a sample, these programs are unlikely to appropriately address exposure to these chemicals. Thus, there is a strong need for similar validation and harmonization programs as they currently exist in the field of chemical risk assessment. In fact, it may be beneficial to draw on the extensive experiences and "lessons learned" from current chemical screening and assessment programs such as the EDSP. Finally, current research and regulatory strategies tend to focus on human and vertebrate health. Especially form an environmental protection perspective, however, the group of invertebrates represents an ecologically very important factor as they form the basis for most food-webs. Thus, in favor of a holistic approach and the improvement of current environmental risk assessment strategies, there is urgent need for establishing tools and approaches that enable the characterization and evaluation of EDC effects in invertebrates.

\section{Acknowledgements}

The authors would like to express their thanks to Dr. Thomas Frische (Environmental Protection Agency, Dessau, Germany) and Dr. Inge Werner (Oekozentrum, EAWAG/EPFL, Duebendorf, Switzerland) for their review of this manuscript and helpful comments.

\section{Author details}

${ }^{1}$ Toxicology Centre, University of Saskatchewan, 44 Campus Drive, Saskatoon, SK S7N 5B3, Canada ${ }^{2}$ Department of Ecosystem Analysis, Institute for Environmental Research, RWTH Aachen University, Worringerweg 1, 52074 Aachen, Germany

\section{Authors' contributions}

Both authors contributed in equal parts to this publication. All authors read and approved the final manuscript.

\section{Competing interests}

The authors declare that they have no competing interests.

Received: 10 February 2011 Accepted: 31 March 2011

Published: 31 March 2011

\section{References}

1. Tyler CR, Jobling S, Sumpter JP: Endocrine disruption in wildlife: A critical review of the evidence. Critical Reviews in Toxicology 1998, 28: 319-361.

2. Crisp TM, Clegg ED, Cooper RL, Wood WP, Anderson DG, Baetcke KP, Hoffmann JL, Morrow MS, Rodier DJ, Schaeffer JE, Touart LW, Zeeman MG, Patel YM: Environmental endocrine disruption: an effects assessment and analysis. Environmental Health Perspectives 1998, 106(Suppl 1): 11-56.

3. Kloas W, Urbatzka R, Opitz R, Wurtz S, Behrends T, Hermelink B, Hofmann F, Jagnytsch O, Kroupova H, Lorenz C, Neuman N, Pietsch C, Trubiroha A, Van Ballegooy, Wiedemann C, Lutz I: Endocrine Disruption in Aquatic Vertebrates. In Trends in Comparative Endocrinology and Neurobiology Annals of the New York Academy of Sciences Edited by: Vaudry H, Roubos EW, Coast GM, Vallarino M 2009, 1163: 187-200.

4. Sumpter JP: The ecotoxicology of hormonally active micropollutants. Water Science and Technology 2008, 57: 125-130.

5. Jobling S, Nolan M, Tyler CR, Brighty G, Sumpter JP: Widespread sexual disruption in wild fish. Environmental Science \& Technology 1998, 32: 2498-2506.

6. Hecker M, Tyler CR, Maddix S, Karbe L: Plasma biomarkers in fish provide evidence for endocrine modulation in the Elbe River, Germany. Environ Sci Technol 2002, 36: 2311-2321.

7. Kidd KA, Blanchfield PJ, Mills KH, Palace VP, Evans RE, Lazorchak JM, Flick RW: Collapse of a fish population after exposure to a synthetic estrogen. Proceedings of the National Academy of Sciences of the United States of America 2007, 104: 8897-8901.

8. EC: European Commission. DIRECTIVE 2000/60/EC OF THE EUROPEAN PARLIAMENT AND OF THE COUNCIL of 23 October 2000 establishing a framework for Community action in the field of water policy 2000, 73, OJ L 327, 22.12.2000.

9. EDSTAC: Endocrine disruptor screening and testing advisory committee final report U.S. Environmental Protection Agency; 1998 [http://www.epa.gov/ endo/pubs/edspoverview/finalrpt.htm].

10. WHO: Report of the Joint IPCS-Japan Worokshop on "Endocrine disruptors: Research needs and future directions". Report Prepared for the WHO/UNEP/ILO International Programme on Chemical Safety (IPCS) 2004, 52, WHO/IPCS/ EDC/01/04.

11. EC: European Commission. Communication from the commission to the council and the European Parliament: Community Strategy for Endocrine Disrupters - a range of substances suspected of interfering with the hormone systems of humans and wildlife. COM(1999) 706 final, 17.12.1999 Brussels, Belgium; 1999, 31.

12. EC: European Commission. Commision staff working document on the implementation of the "Community Strategy for Endocrine Disrupters" - a 
range of substances suspected of interfering with the hormone systems of humans and wildlife (COM (1999) 706), (COM (2001) 262) and (SEC (2004) 1372). SEC(2007) 1635, 30.11.2007 2007, 37

13. WHO: Global assessment of the state-of-the-science of endocrine disruptors. Report Prepared for the WHO/UNEP/ILO International Programme on Chemical Safety (IPCS). WHO/PCS/EDC/02.2 2002, 180.

14. Regulation (EC) No 1107/2009: European Parliament and of the Council of 21 October 2009 concerning the placing of plant protection products on the market and repealing Council Directives 79/117/EEC and 91/414/EEC 2009.

15. Karabelas AJ, Plakas KV, Solomou ES, Drossou V, Sarigiannis DA: Impact of European legislation on marketed pesticides - A view from the standpoint of health impact assessment studies. Environ Int 2009, 35 : 1096-1107.

16. OECD: OECD conceptual Framework for the Testing and Assessment of Endocrine Disrupting Chemicals 2002 [http://www.oecd.org/dataoecd/17/33/ 23652447.doc].

17. Burkhardt-Holm P: Endocrine Disruptors and Water Quality: A State-ofthe-Art Review. International Journal of Water Resources Development 2010, 26: 477-493

18. Adler P, Steger-Hartmann T, Kalbfus W: Vorkommen natürlicher und synthetischer östrogener Steroide in Wässern des süd- und mitteldeutschen Raumes [Distribution of natural and synthetic estrogen steroid hormones in water samples from southern and middle Germany]. Acta hydrochimica hydrobiologica 2001, 29: 227-241.

19. Wölz J, Fleig M, Schulze T, Maletz S, Lübcke-von Varel U, Reifferscheid G, Kühlers D, Braunbeck T, Brack W, Hollert H: Impact of contaminants bound to suspended particulate matter in the context of flood events. Journal of Soils and Sediments 2010, 10: 1174-1185.

20. Kühlers D, Bethge E, Hillebrand G, Hollert H, Fleig M, Lehmann B, Maier D, Maier M, Mohrlok U, Wölz J: Contaminant transport to public water supply wells via flood water retention areas. Natural Hazards and Earth System Science 2009, 9: 1047-1058.

21. Pinto B, Reali D: Screening of estrogen-like activity of mineral water stored in PET bottles. International Journal of Hygiene and Environmental Health 2009, 212: 228-232.

22. Wagner $M$, Oehlmann J: Endocrine disruptors in bottled mineral water: total estrogenic burden and migration from plastic bottles. Environmental Science and Pollution Research 2009, 16: 278-286.

23. Canada-Gazette: Part II. 2010, 144(21): 1806-18.

24. Rodgers-Gray TP, Jobling S, Kelly C, Morris S, Brighty G, Waldock MJ, Sumpter JP, Tyler CR: Exposure of juvenile roach (Rutilus rutilus) to treated sewage effluent induces dose-dependent and persistent disruption in gonadal duct development. Environmental Science \& Technology 2001, 35: 462-470.

25. Desbrow C, Routledge EJ, Brighty GC, Sumpter JP, Waldock M: Identification of Estrogenic Chemicals in STW Effluent. 1. Chemical Fractionation and in Vitro Biological Screening. Environ Sci Technol 1998, 32: 1549-1558.

26. Hollert $H$, Durr M, Holtey-Weber $R$, Islinger $M$, Brack W, Farber $H$, Erdinger $L$, Braunbeck T: Endocrine disruption of water and sediment extracts in. a non-radioactive dot blot/RNAse protection-assay using isolated hepatocytes of rainbow trout - Deficiencies between bioanalytical effectiveness and chemically determined concentrations and how to explain them. Environmental Science and Pollution Research 2005, 12: 347-360.

27. Grund S, Higley E, Schönenberger R, Suter MJF, Giesy JP, Braunbeck T, Hecker $M$, Hollert $H$ : The endocrine disrupting potential of sediments from the Upper Danube River (Germany) as revealed by in vitro bioassays and chemical analysis. Environmental Science and Pollution Research 2010, 18: 446-460

28. Gracia T, Jones PD, Higley EB, Hilscherova K, Newsted JL, Murphy MB, Chan KY, Zhang X, Hecker M, Lam PKS, Wu RSS, Giesy JP: Modulation of steroidogenesis by coastal waters and sewage efluents of Hong Kong, China, using the H295R assay. Environ Sci Pol Res 2007, 332-343.

29. Keiter S, Rastall A, Kosmehl T, Wurm K, Erdinger L, Braunbeck T, Hollert H: Ecotoxicological assessment of sediment, suspended matter and water samples in the upper Danube River - A pilot study in search for the causes for the decline of fish catches. Environmental Science and Pollution Research 2006, 13: 308-319.

30. Blaha L, Hilscherova K, Mazurova E, Hecker M, Jones PD, Newsted JL, Bradley PW, Gracia T, Duris Z, Horka I, Holoubek I, Giesy JP: Alteration of steroidogenesis in H295R cells by organic sediment contaminants and relationships to other endocrine disrupting effects. Environ Int 2006, 32: 749-757.

31. Hecker M, Hollert H: Effect-directed analysis (EDA) in aquatic ecotoxicology: State of the art and future challenges. Environmental Science and Pollution Research 2009, 16: 607-613.

32. Brack W, Klamer HJ, Lopez de Alda M, Barcelo D: Effect-directed analysis of key toxicants in European river basins a review. Environ Sci Pollut Res Int 2007, 14: 30-38

33. Oehlmann J, Oetken M, Schulte-Oehlmann U: A critical evaluation of the environmental risk assessment for plasticizers in the freshwater environment in Europe, with special emphasis on bisphenol $\mathrm{A}$ and endocrine disruption. Environmental Research 2008, 108: 140-149.

34. Stalter D, Magdeburg A, Oehlmann J: Comparative toxicity assessment of ozone and activated carbon treated sewage effluents using an in vivo test battery. Water Research 2010, 44: 2610-2620.

35. Hecker M, Giesy JP: Effect-directed analysis of Ah-receptor mediated toxicants, mutagens and endocrine disruptors in sediments and biota. In Handbook of Environmental Chemistry on EDA. Edited by: Brack W. Heidelberg: Springer; 2011:

36. Brack W, Schirmer K, Erdinger L, Hollert H: Effect-directed analysis of mutagens and ethoxyresorufin-O-deethylase inducers in aquatic sediments. Environmental Toxicology and Chemistry 2005, 24: 2445-2458.

37. Houtman CJ, Cenijn PH, Hamers T, Lamoree MH, Legler J, Murk AJ, Brouwer A: Toxicological profiling of sediments using in vitro bioassays, with emphasis on endocrine disruption. Environmental Toxicology and Chemistry 2004, 23: 32-40.

38. Machala M, Ciganek M, Blaha L, Minksova K, Vondrack J: Aryl hydrocarbon receptor-mediated and estrogenic activities of oxygenated polycyclic aromatic hydrocarbons and azaarenes originally identified in extracts of river sediments. Environmental Toxicology and Chemistry 2001, 20 2736-2743.

39. Mazurova E, Hilscherova K, Jalova V, Kohler HR, Triebskorn R, Giesy JP, Blaha $L$ : Endocrine effects of contaminated sediments on the freshwater snail Potamopyrgus antipodarum in vivo and in the cell bioassays in vitro. Aquatic Toxicology 2008, 89: 172-179.

40. Netzband A, Brils J, Brauch HJ, Liska I, Miloradov M, Nachtnebel HP, Pirker O, Rast G, Almodovar M, Dias EB, Gomes FV, Heise S, Portela L, Vale C, Forstner U, Gabriel T, Heininger P, Sassen K, Schulz S, Brien J, Morris R, Owens P, White S, Whitehead P, Winn P, den Besten P, Della Sala S, Eisma M, Hauge A, Keller M, Slob A: Sediment management: An essential element of river basin management plans. Journal of Soils and Sediments 2007, 7: 117-132.

41. Hollert H, Heise S, Keiter S, Heininger P, Förstner U: European water framework Directive - Progress and shortcomings/ Wasserrahmenrichtlinie - WRRL Wasserrahmenrichtlinie - Fortschritte und Defizite. Umweltwissenschaften und Schadstoff-Forschung 2007, 19 58-70.

42. Hollert $H$, Ernst $M$, Ahlf W, Dürr M, Erdinger L, Grund $S$, Keiter $S$, Kosmehl T, Seiler TB, Wölz J, Braunbeck T: Strategies for assessing sediment toxicity A review/Strategien zur Sedimentbewertung - Ein Überblick. Umweltwissenschaften und Schadstoff-Forschung 2009, 21: 160-176.

43. Hollert $\mathrm{H}$ : Entwicklung eines kombinierten Untersuchungssystems für die Bewertung der ökotoxikologischen Belastung von Fließgewässersedimenten und -schwebstoffen. Dissertation, Fakultät für Biologie der Universität Heidelberg 2001, 258 [http://www.ub.uni-heidelberg. de/archiv/1602].

44. Stalter D, Magdeburg A, Weil M, Knacker T, Oehlmann J: Toxication or detoxication? In vivo toxicity assessment of ozonation as advanced wastewater treatment with the rainbow trout. Water Research 2010, 44: 439-448.

45. Ternes TA, Stumpf M, Mueller J, Haberer K, Wilken RD, Servos M: Behavior and occurrence of estrogens in municipal sewage treatment plants-I. Investigations in Germany, Canada and Brazil. Sci Total Environ 1999, 225 : 81-90.

46. Ternes TA, Kreckel P, Mueller J: Behaviour and occurrence of estrogens in municipal sewage treatment plants-II. Aerobic batch experiments with activated sludge. Sci Total Environ 1999, 225: 91-99.

47. Jobling S, Coey S, Whitmore JG, Kime DE, Van Look KJ, McAllister BG, Beresford N, Henshaw AC, Brighty G, Tyler CR, Sumpter JP: Wild intersex roach (Rutilus rutilus) have reduced fertility. Biol Reprod 2002, 67: 515-524. 
48. Onesios KM, Yu JT, Bouwer EJ: Biodegradation and removal of pharmaceuticals and personal care products in treatment systems: a review. Biodegradation 2009, 20: 441-466.

49. Flohr T, Maletz S, Schönlau C, Higley E, Hecker M, Hollert H: Effects of Effluent Sample Extracts (Micropoll) using the H295R Steroidogenesis and the Potamopyrgus antipodarum sssay. Report prepared for: Oekotoxzentrum, Eawag/EPFL, Duebendorf, Switzerland. 2011, 15.

50. Kienle C, Kase R, Werner I: Evaluation of bioassays and wastewater quality - In vitro and in vivo bioassays for the performance review in the Project "Strategy MicroPoll". Summary report. Dübendorf, Swiss Centre for Applied Ecotoxicology, Eawag/EPFL 2011

51. Higley E, Hecker M: Assessment of the Effects of Effluent Sample Extracts (Micropoll) on the Production of Testosterone and 17beta-Estradiol Using the H295R Steroidogenesis Assay. Report prepared for: Oekotoxzentrum, Eawag/EPFL, Duebendorf, Switzerland 2011, 15.

52. Weil M: Results of fish egg test with Danio rerio, fish early life stage test with rainbow trout and sediment-water toxicity test with L. variegatus. Proceedings Strategy Micropoll, 4th Meeting of the expert group ecotoxicology 2010.

53. Nakada N, Shinohara H, Murata A, Kiri K, Managaki S, Sato N, Takada H: Removal of selected pharmaceuticals and personal care products (PPCPs) and endocrine-disrupting chemicals (EDCs) during sand filtration and ozonation at a municipal sewage treatment plant. Water Research 2007, 41: 4373-4382.

54. US-EPA: Removal of Endocrine Disruptor Chemicals Using Drinking Wate Treatment Processes. $R$ \& D Technology Transfer Document Number EPA 625/R-00/015 U.S. Environmental Protection Agency, Washington, DC, USA; 2001.

55. Leusch F: Tools to Detect Estrogenic Activity in Environmental Waters. Global Water Research Coalition 20082008.

56. Kase R, Kunz P, Gerhardt A: Identifikation geeigneter Nachweismoeglichkeiten von homronaktiven und reproduktionstoxischen Wirkungen in aquatischen Oekosystemen. Umweltwiss Schadst Forsch 2009, 21: 339-378.

57. Folmar LC, Hemmer MJ, Denslow ND, Kroll K, Chen J, Cheek A, Richman H, Meredith $\mathrm{H}$, Graue EG: A comparison of the estrogenic potencies of estradiol, ethynylestradiol, diethylstilbestrol, nonylphenol and methoxychlor in vivo and in vitro. Aquat Toxicol 2002, 60: 101-110.

58. Charles GD, Kan HL, Schisler MR, Bhaskar Gollapudi B, Sue Marty M: A comparison of in vitro and in vivo EDSTAC test battery results for detecting antiandrogenic activity. Toxicol Appl Pharmacol 2005, 202: 108-120.

59. Knacker T, Boettcher $M$, Frische T, Rufli $H$, Stolzenberg H-C, Teigeler $M$, Zok S, Braunbeck T, Schäfers C: Environmental effect assessment for sexual endocrine-disrupting chemicals: Fish testing strategy. Integrated Environmental Assessment and Management 2010, 6: 653-662.

60. Kramer VJ, Etterson MA, Hecker M, Murphy CA, Roesijadi G, Spade DJ, Spromberg JA, Wang M, Ankley GT: Adverse outcome pathways and ecological risk assessment: Bridging to population level effects. Environ Technol Chem 2010, 30(1): 64-76.

61. Thomas KV, Hurst MR, Matthiessen P, Waldock MJ: Characterization of estrogenic compounds in water samples collected from United Kingdom estuaries. Environ Toxicol Chem 2001, 20: 2165-2170.

62. Houtman CJ, Van Oostveen AM, Brouwer A, Lamoree MH, Legler J: Identification of estrogenic compounds in fish bile using bioassaydirected fractionation. Environmental Science \& Technology 2004, 38 6415-6423.

63. Oehlmann J, Schulte-Oehlmann U: Endocrine disruption in invertebrates. Pure and Applied Chemistry 2003, 75: 2207-2218.

64. deFur PL, Crane M, Ingersoll C, Tattersfield L: Endocrine Disruption in Invertebrates Endocrinology, Testing, and Assessment. Proceedings of the Workshops on Endocrine Disruption. In: Invertebrates, 12-15 December 1998, Noordwijkerhout, The Netherlands Pensacola: SETAC Press; 1999.

65. Lemos MFL, van Gestel CAM, Soares AMVM: Endocrine disruption in a terrestrial isopod under exposure to bisphenol A and vinclozolin. I Soil Sed 2009, 9: 492-500

doi:10.1186/2190-4715-23-15

Cite this article as: Hecker and Hollert: Endocrine disruptor screening: regulatory perspectives and needs. Environmental Sciences Europe 2011 23:15.

\section{Submit your manuscript to a SpringerOpen ${ }^{\mathcal{O}}$ journal and benefit from:}

- Convenient online submission

- Rigorous peer review

- Immediate publication on acceptance

- Open access: articles freely available online

- High visibility within the field

- Retaining the copyright to your article

Submit your next manuscript at $\gg$ springeropen.com 